\title{
Cultural Heritage of Social Ethics in Javanese Manuscript of Sêrat Sarawungan
}

\author{
Istanti Fatkhul Janah, S Sumarlam, Nugraheni Eko Wardani
}

Postgraduate Program, Javanese Language and Letters Education, Universitas Sebelas Maret (UNS) of Surakarta

Jl. Ir. Sutami No. 36 A, Jebres, City of Surakarta, Central Java, 57126

E-mail: istanti92@gmail.com

\begin{abstract}
This study discusses social ethics reflected in Sêrat Sarawungan manuscript as a cultural heritage which focuses on the aspect of social ethics. The purpose of this study is to explore the social ethics in inculcating the youth towards with Javanese excellent characters that sourced from Serat Sarawungan. This study uses a textual theoretical framework and ethics, to explore the social ethics manifested from the object of study as a lesson learned for the younger generation through Javanese noble characters. The object of this study is Sêrat Sarawungan text which is part of Sêrat Têpa Palupi By Gus Sariph from Kediri which was later written by R. Pujaarja of Surakarta in 1832. The manuscript which is a collection of Radya Pustaka Surakarta Museum, the text generally tells about the story of Gus Bantong's journey to various regions in seeking for knowledge. In the midst of his journey, he wrote a Serrat Sarawungan which contained social ethics that was relevant in the social life of the community especially Java. This study uses a qualitative research paradigm procedure. Data collection in the form of words, phrases, and sentences using the library method. Analysis and interpretation of data using the hermeneutic reading method. The results of this study are the kinds of social ethics reflected in Sêrat Sarawungan text which can then further be evaluated as learning material in an effort of inculcating the Javanese noble characters to the youth.
\end{abstract}

Keywords: Manuscript, Sêrat Sarawungan, Ethics, Javanese

\section{INTRODUCTION}

Indonesia is a developing country which is currently afflicted by globalization. One of the negative impacts of globalization especially to the Indonesian people is on the loss of a spirit in inculcating the national character values [1]. The loss of national character values resulted in at least the Indonesian people forgetting about national character education [2]. On the other hand the positive impact of globalization has proven to facilitate many aspects of human life, one of 
which is the presence of sophisticated tools that come up amid the society making everything easy, however, the excessive needs change people's lifestyles as social beings lose their identity. This does not imply the fact that various life activities can be fulfilled through sophisticated tools or gadget. This has at least influenced the pattern of life in society, especially young people. The young people become addicted to the gadget, making them feel stiff in interacting with the real community around.. Certainly, this condition has led the young generation ignoring the prevailing etiquette or unggah-ungguh in Javanese environment society.

The Indonesian nation is identical to the world as a nation whose characters associated with the eastern culture, i.e, in regard to personal manners, friendliness, mutual help, mutual cooperation etc. This eastern culture, especially Javanese, is one of the BIPA's teaching materials for reflects the unique and distinctive local values[3]. This is precisely fact happening to the youth living in current Indonesia. Instead of being proud of their cultural origin, they tend to be more comfortable with other nation's culture, let's say the western culture. The mass culture has changed the national character of Pancasila culture towards liberal, and capitalist culture. Hedonistic lifestyles, individualistic attitudes, are portraits of the mass culture eroding to our nation's identity as a cultured and civilized nation [4]. Such circumstance leads the Indonesian nation to be underestimated by other countries.

This study attempts to explore several significant things related to social ethics in ancient Javanese texts entitled Sêrat Sarawungan. Manuscripts are one of the cultural heritage of the Indonesian people, whose existence holds information in the past reflecting thoughts, feelings, beliefs, customs, and values of the heritage of the past[5]. In particular, Javanese manuscripts are "sources of traditional documents of either text or writing forms, handwritten or printed, which manifest the thoughts and feelings of the author of his age" [6]. The Javanese written manuscript titled Sêrat Sarawungan is partly the chapter in Sêrat Têpapalupi, a collection of the Yayasan Sastra Lestari which is accessible online through sastra.org, it contains various social ethics further specifically discussed in this article. Meanwhile, ethics is typically one of the cultural embodiments and mostly defined as the fundamental moral philosophy. Thus, ethics is a science or systematic reflection about opinions, norms, and moral terms [7].

Several important studies have navigated the exploration on the Javanese indigenous sides of local values manifested in ancient manuscript texts as an effort to reviving the noble teaching characters, among the studies came up with their results, for example, 1) Sumiyardana [8] who addressed ethical values in Sêrat Wuruk Respati, 2) [1] discussed the contribution of Sasak manuscript in establishing the national character, 3) Susiyanto [9] who discussed Satra Wulang manuscript-based moral learning, 4) Chasanah [10] discussed the children education in Sêrat Wulang Sunu a work by Paku Buwono IV and 5) Saddhono [11] who discussed about the rule of Dutch colonialism in the political life of Mataram Dynasty narrated in Babad Tanah Jawi manuscript. In this study, the Javanese community's social ethics will be explored from the Sêrat Sarawungan.

\section{RESEARCH METHOD}

This study follows the qualitative research model by understanding the phenomena experienced by research subjects holistically and by way of descriptions typically from the words use and language aspects in general, in a special natural context and by utilizing various natural methods [12]. This study applied a textual approach that concerns examining the linguistic elements of discourses which specifically analyze prose-typical texts. The analysis 
technique used an interactive work model covering the three components, namely the data reduction, data presentation, and verification that primarily discuss the texts and ethics of socialization. The data were collected through the library method with the primary data source is the Sêrat Sarawungan manuscript. On the basis of the qualitative data, this study was developed from the qualitative-descriptive analysis method. The described data is necessarily the work process output from the hermeneutic reading activity, which is the back and forth reading or retroactively. In addition, both reductions and conclusions were also made in analyzing the data. The data in this study are words, phrases, and sentences which reflect the social ethics elements. The validity of the data was tested through triangulation [13]

\section{RESULTS AND DISCUSSION}

This section discusses social ethics manifested from Sêrat Sarawungan manuscript as the Javanese cultural heritage that expectedly will inspire a young generation about the Javanese noble characters.

\subsection{The Ethics in Socializing Based on the Social Status/Stratification}

Social stratification is an element of differentiation or grouping of a community member vertically (multilevel). Social stratification is influenced by various factors including; position factor or position, education, economic level, lineage, and so on. The position here is divided into three, namely; equivalent stratification, stratification above and stratification below. Ethics associate based on social stratification, which is:

“. . . yèn sarawungan karo wong sapadha, patrape sing madya, têmbunge sing prasaja. Yen sarawungan karo sadhuwure, patrape aja mapaki, tembunge aja madhan. Yen sarawungan karo wong sangisore, patrape aja ngungkuli, tembunge aja madhani. . ." (Pujaraja, 1832: 101-102)

Free translation:

". . . if someone associates with those who are equal in their social stratification, they should behave appropriately, should speak in simple, gentle words. If you associate with people with higher social stratification, you should not be equal in behaving, talk in unequal words to humble yourself. If someone associates with those with lower social stratification, he or she should not be pretentious in behaving, if he or she speaks, do not use condescending words..." (Pujaraja, 1832: 101-102)

In Sêrat Sarawungan, which explained that the ethics of socializing with other people of similar social stratification, one should behave appropriately. The meaning of social stratification similarly defined as having the equal position, both in education, employment, status and so forth. The fair measuring criteria of behaving with people who share similar social stratification means assuming these people equally from anyone else including him/herself, neither think other higher than him/anyone nor they are inferior. In addition, if one speaks, he/she should use gentle words. The simple words mean the use of sentences that are commonly used by people upon communicating with those who share similar social stratification. In the case of the Javanese language conversations, people concern the use of Javanese moderate words, neither the variety of krama inggil nor ngoko, this is used because both speakers have already known each other. 
Unlike showing the ethics in socializing with those of higher social stratification, one should behave andhap asor or being modest. The modesty is traditionally known as patrap , this is shown at the time one is talking one another, that he/she should not look directly into the eyes of the interlocutor and bow down at the time walking before him. In addition, in case one has to speak to the interlocutor of higher social status, instead of using language at the general environment, he/she should use Javanese in a variety of manners. That way, people who have a lower position will be more appreciated or ngajeni towards people of socially upper than him. Similarly, people of upper social status will feel more esteemed or 'diajeni'.

Furthermore, the ethics in socializing towards people of lower social stratification such as children, younger siblings, pupils, students, juniors, assistants, and others. In Sêrat Sarawungan, in case one socialize with people of lower social status one should not behave arrogantly and feel higher. The arrogant character and feeling him/herself higher are seen for example with the attitude of waistline or cumanthaka. Additionally, in Sêrat Sarawungan it is suggested that in case one wishes to talk people of lower in their social status, they should use words that do not offend the person who he/she talks to. One of the examples of offending words such as calling one with his/her unpleased nickname paraban that would at the end offend their feelings. Another example is when one criticizes or giving suggestion with gentle words of wisdom instead of the degrading words. Therefore, people of below social status shall feel to be respected or diayomi.

\subsection{Social Ethics Based on the Economic Capabilities}

One of the things distinguishing social status is the level of one's economic ability, there is inevitably dichotomous relationship between the rich and poor. In socializing, one should not take seriously about other people's economic position, some people bear take economic. Although it should not be discriminating in terms of economics in socializing. The social ethics associating with people based on differences in economic abilities, which is:

“. . . yen sarawungan karo wong mlarat, patrape aja siya, tembunge sing katon rena. Yen sarawungan karo wong sugih, patrape aja wigah-wigih, tembunge sing ngasihasih. .." (Pujaraja, 1832: 102)

Free translation:

". . . if [you] socialize with those who are poor people should not be arbitrary, keep the conversation with good and pleasant words. If you hang out with rich people, you should not be too rigid, talk with gentle words. "(Pujaraja, 1832: 102)

According to Sêrat Sarawungan basically, those who are poor are not worthy of being dishonored. The dishonorable treatment involves mocking or demeaning others. Besides that, they promised to deliberately deny or give something arrogantly. When one thinks it is necessary to talk to those of poor, one needs to gentle words and motivate them. Thus, those in the economy above will not be arrogant. This teaching implicates in Javanese philosophy that emphasizes sugih tanpa bandha which means the benchmark of a rich person basically lies not only in wealth but with the wealth of his heart.

On the other hand, Sêrat Sarawungan explains in behaving and socializing with those of the richer one should be flexible. As for being flexible in this case, he/she should not overestimate the richer. The flexibility of a person is also shown by anxious fear of being inappropriate. In this case, it is recommended for a person to behave appropriately and keep 
adhering to the ethics of Javanese modesty. Additionally, Sêrat Sarawungan suggested a noble Javanese ethic at the time when one holds a conversation with those of richer community with gentle words. These gentle words are then interpreted as expressing polite words. A person is not allowed to seek mercy before the rich people, even though his own economic level is at the lower level, the most important thing of all is how he should be able to maintain his self-esteem.

\subsection{Social Ethics Based on the Academic Capabilities}

This section discusses social ethics based on one's academic abilities. Academic ability is characterized by various factors. One of the most influencing factors is one's education level. Although this is not the first benchmark it is very important. Ethics of socializing with people are based on academic abilities as stated in the manuscript:

“. . .yen sarawungan karo wong busuk, patrape aja corak-caruk, tembunge sing empuk. Yen sarawungan karo wong wignya, patrape aja kuciwa, tembunge kudu sujana. .." (Pujaraja, 1832: 102)

Free translation:

“. . . if [you] are socializing with those who are less intelligent or ignorant, you should not act carelessly, talk to them with gentle words. If you hang out with someone who is smart, you should not be discouraged, speak to them with noble words". (Pujaraja, 1832: 102)

Almost the same as the ethics of association with people who have a low or poor economic level, Sêrat Sarawungan additionally shows the social ethics with people less smart or ignorant. In socializing with people of low economic income who should not abuse their speaking partners. The social abuse in this regards means, one communicates to his/her speaking partner(s) as he/she pleased ignoring other people's feelings. Thus, in order not to give the impression of patronizing the interlocutor, this also helps speakers to avoid being claimed as someone who knows everything (kêmêruh) feeling him/herself the smartest (kêmintêr). In communicating with these people, one is suggested to speak gently. A gentle word concerns about speaking of words that do not either intentionally or unintentionally hurt other people's feelings. As a Javanese, this typical communication is not characterized by the Javanese speech variation of krama inggil but ngoko lugu speech variation. This is primarily done to avoid the assumption of degrading the speaking partner(s).

On the other hand, in Serrat Sarawungan, it is emphasized that those who feel smarter are those who were given the opportunity and advantage of seeking knowledge from the person they are talking to. The manuscript explained in a matter of socializing with the smarter people, one should not be discouraged. In addition, it was also explained that if one communicates with those of the smarter, one needs to speak with noble words. The noble words can be gentle words, the selected words according to the level of the community or speaking a person's intelligence. Bearing the importance of having this understanding, one does not assume feeling more knowledgeable than the others, this is a vital little thing affecting the social cohesion.

\section{CONCLUSION}

The conclusion of this social ethics study of Sêrat Sarawungan as an indigenous cultural heritage reflects well-maintained various kinds of social ethics. The described ethics are 
classified into three based, namely; 1) social stratification, 2) economic level, and 3) academic ability. When these have greatly affected the community's social life, social ethics should then be able to be reflected in people's everyday life. By this manuscript, the youth will hopefully take consideration on the virtue of Javanese character in a way of strengthening the eastern customs. Through this study, the young people of the succeeding generation of Indonesia are expected to be a nation that typically upholds the noble character and strength in addition to enhancing the dignity of the Indonesian people internationally.

\section{REFERENCES}

[1] J. Jamaluddin, "Kontribusi Naskah Sasak bagi Pembentukan Karakter Bangsa," Manuskripta, vol. 7, no. 1, pp. 97-118, 2017.

[2] M. Muslich, Pendidikan Karakter: Menjawab Tantangan Krisis Multidimensional. Jakarta: PT Bumi Aksara, 2011.

[3] K. Saddhono, "Cultural and social change of foreign students in Indonesia: The influence of Javanese Culture in Teaching Indonesian to Speakers of Other Languages (TISOL)," IOP Conf. Ser. Earth Environ. Sci., vol. 126, p. 12091, 2018.

[4] S. Supriyono, N. E. Wardani, and K. Saddono, "Pendidikan Karakter Berbasais Sastra Sejarah dalam Puisi 'Aku Tidak Bisa Menulis Puisi Lagi' Karya Subagio Sastrowardoyo," J. Artefak Hist. Educ., vol. 4, no. 2, 2017.

[5] S. B. Baried, Pengantar Teori Filologi. Yogyakarta: Badan Penelitian dan Publikasi Fakultas (BPPF) seksi Filologi Fakultas Sastra Universitas Gajah Mada, 1994.

[6] A. Basuki, M. Thohir, M. Abdullah, T. Y. Muzakka, and Rukiyah, Pengantar Filologi. Semarang: Fasindo, 2004.

[7] F. M. Suseno, Etika Jawa: Sebuah Analisa Falsafi tentang Kebijaksanaan Hidup Jawa. Jakarta: Gramedia, 2003.

[8] K. Sumiyardana, "Nilai-Nilai Etika Dalam Sêrat Wuruk Respati," J. Kaji. Kebud., vol. 1, no. 1, 2017.

[9] Susiyanto, "Pengajaran Akhlak Berbasis Naskah Sastra Wulang," J. Stud. dan Penelit. Pendidik. Islam, vol. 1, no. 1, pp. 72-84, 2018.

[10] Chasanah and Iflahathul, "Pendidikan Anak Dalam Sêrat Wulang Sunu Karya Sunan Pakubuwono II: Sebuah Analisis Isi," J. Cendekia, vol. 16, no. 2, 2018.

[11] K. Saddhono and S. Supeni, "The Role of Dutch Colonialism in the Political Life of Mataram Dynasty: A Case Study of the Manuscript of Babad Tanah Jawi," Asian Soc. Sci., vol. 10, no. 15, 2014.

[12] L. J. Moleong, Metodologi Penelitian Kualitatif. Bandung: Remaja Rosda Karya., 2007.

[13] Siswantoro, Metode Penelitian Sastra: Analisis Struktur Puisi. Yogyakarta: Pustaka Pelajar, 2010. 